\title{
Cell-Cell Signaling between Adult Rat Ventricular Myocytes and Cardiac Microvascular Endothelial Cells in Heterotypic Primary Culture
}

\author{
Masashi Nishida, Jeremy P. Springhorn, Ralph A. Kelly, and Thomas W. Smith \\ Cardiovascular Division, Departments of Medicine, Brigham and Women's \\ Hospital and Harvard Medical School, Boston, Massachusetts 02115
}

\begin{abstract}
It is unclear whether signaling between endothelial cells and muscle cells within ventricular myocardium, known to be important during cardiac development, remains physiologically relevant in the adult heart. Also, the mechanisms regulating the synthesis and activation of locally acting autacoids such as endothelins, cytokines known to have potent effects on contractile function and gene expression in cardiac myocytes, are unknown, as are their cells of origin within ventricular muscle. Microvascular endothelial cells isolated from ventricular tissue of adult rats do not express endothelins constitutively. However, the appearance of preproendothelin mRNA can be increased in cardiac microvascular endothelial cells by heterotypic primary culture with adult rat ventricular myocytes. Cellcell contact, or at least close apposition, appears to be necessary to increase preproendothelin mRNA, as medium conditioned by ventricular myocytes alone was ineffective when applied to monocultures of microvascular endothelial cells. The level of TGF $\beta$ precursor mRNA is also markedly increased in microvascular endothelial cells in coculture and precedes the appearance of endothelin precursor transcripts. In coculture, TGF $\beta$ acts as an autocrine cytokine, increasing endothelin precursor mRNA and inhibiting the rate of microvascular endothelial cell proliferation. This regulation of endothelial cell phenotype in heterotypic primary cultures suggests that dynamic, reciprocal cell-cell signaling may also be occurring between microvascular endothelium and ventricular myocytes in vivo. (J. Clin. Invest. 1993. 91:1934-1941.) Key words: angiogenesis $\bullet$ cytokine $\bullet$ hypertrophy $\bullet$ endothelin $\bullet$ transforming growth factor- $\beta$
\end{abstract}

\section{Introduction}

The importance of cell-cell interactions during cardiac morphogenesis involving peptide signaling factors, such as acidic and basic fibroblast growth factor and TGF $\beta$ among others, is now well recognized (1-3). Postnatal and adult mammalian ventricular tissue also contains autocrine- and paracrine-acting peptide cytokines, although their relevance to the regulation of myocardial function and gene expression is less clear. Vascular

Address correspondence to Thomas W. Smith, M.D., Cardiovascular Division, Brigham and Women's Hospital, 75 Francis St., Boston, MA 02115.

Received for publication 16 June 1992 and in revised form 3 December 1992

J. Clin. Invest.

(C) The American Society for Clinical Investigation, Inc.

0021-9738/93/05/1934/08 \$2.00

Volume 91, May 1993, 1934-1941 and endocardial endothelial cells are a potential source of these and other peptide cytokines, as well as a number of additional compounds of disparate biological activity that may directly or indirectly affect the function of adjacent cardiac muscle cells $(4,5)$. Since the initial reports by Brutsaert and co-workers $(6$, 7 ), several groups have now confirmed that endocardial endothelium can regulate the inotropic response of subjacent myofibrils $(8,9)$ and that the function of contractile proteins within ventricular muscle may be regulated by factors released from the microvasculature $(10,11)$.

Of those peptide signaling factors of presumed endothelial cell origin detected within the adult heart, endothelins have been among the most extensively characterized, at least in terms of their pharmacological action on cardiac muscle $(4,5$, 12-14). The three endothelin isoforms that have been described are now known to be among the most potent inotropic agents yet identified, with important actions on myocyte gene expression and growth. Endothelins are known to act as autocrine and / or paracrine peptide autacoids, or cytokines, in most tissues in which they have been described $(4,14)$. If endothelins are produced locally within ventricular tissue, the most likely source is the microvasculature, although it is not known whether cardiac microvascular endothelial cells express endothelins.

In this report, the regulation of microvascular endothelial cell phenotype by cardiac myocytes is examined in heterotypic primary culture. Unlike large vessel endothelial cells, evidence for constitutive production of endothelin precursor transcripts could not be detected in cardiac microvascular endothelial cells $(\mathrm{CMEC})^{1}$ at the sensitivity of standard Northern analysis. However, the abundance of endothelin precursor mRNA could be markedly induced by coculture with adult ventricular myocytes. In addition, the rate of endothelial cell proliferation was diminished by coculture. Both effects were preceded by increasing levels of TGF $\beta$ mRNA within endothelial cells in coculture and could be blocked by TGF $\beta$-specific antibodies.

\section{Methods}

Coculture of adult rat ventricular myocytes (ARVM) and CMEC. Ventricular myocytes were isolated from adult rat hearts as previously described (15). Briefly, hearts from male Sprague-Dawley rats (175-200 g) were perfused retrogradely with nominally $\mathrm{Ca}^{2+}$-free $\mathrm{Krebs-Hense-}$ leit bicarbonate (KHB) buffer, minced, and dissociated with an enzyme mixture consisting of KHB buffer with added trypsin $(0.02 \mathrm{mg} /$ $\mathrm{ml})$ and deoxyribonuclease $(0.02 \mathrm{mg} / \mathrm{ml})$. Dissociated filtered cells were sedimented twice through a $6 \%$ BSA cushion. The final pellet was resuspended in DME plus $20 \% \mathrm{FCS}, 10 \mu \mathrm{g} / \mathrm{ml}$ of cytosine arabinoside,

1. Abbreviations used in this paper: ARVM, adult rat ventricular myocytes; CMEC, cardiac microvascular endothelial cells; $\mathrm{EC}_{\mathbf{5 0}}$, median effective concentration; KHB, Krebs-Henseleit bicarbonate. 
and penicillin $(100 \mathrm{IU} / \mathrm{ml}) /$ streptomycin $(100 \mu \mathrm{g} / \mathrm{ml})$ and plated on laminin-coated culture dishes $\left(1 \mu \mathrm{g} / \mathrm{cm}^{2}\right)$ at a density of $8.5 \times 10^{3}$ cells $/ \mathrm{cm}^{2}$. The medium was changed and the cells rinsed briefly once at $45 \mathrm{~min}$ to remove loosely attached residual nonmyocyte cells.

The methods for isolation of rat CMEC and their characterization have been described in detail elsewhere (16). Briefly, the atria, valvular tissue, and right ventricle were removed and the remainder of the left ventricle was briefly immersed ( $30 \mathrm{~s}$ ) in $70 \%$ ethanol to devitalize epicardial mesothelial and endocardial endothelial cells. The outer onequarter of the ventricular free wall was removed, and the remaining ventricular tissue was minced finely and treated with collagenase and trypsin in nominally $\mathrm{Ca}^{2+}$-free $\mathrm{KHB}$ buffer. Dissociated cells were washed and resuspended in DME with 20\% FCS and penicillin/streptomycin and plated on laminin- $\left(1 \mu \mathrm{g} / \mathrm{cm}^{2}\right)$ coated culture dishes at a density of 2,500 cells $/ \mathrm{cm}^{2}$. These primary isolates of CMEC from adult rat hearts have previously been documented to contain $>90 \%$ microvascular endothelial cells as judged by a number of criteria, including fluorescence-activated cell sorting of cells labeled with a fluorescent derivative of acetylated LDL (16).

The coculture format used in the experiments described here unless otherwise stated was heterotypic primary culture, in which primary isolates of CMEC were plated at the density noted above on established primary cultures of ARVM, $7 \mathrm{~d}$ after myocyte isolation and after removal of cytosine arabinoside. Cocultures were initiated in DME $+20 \%$ FCS with penicillin/streptomycin. Medium conditioned by date-matched homotypic primary cultures of CMEC or heterotypic cultures of CMEC and ARVM was harvested on days 5 and 6 and immediately diluted with fresh DME with $20 \%$ FCS ( $1: 1$, vol $/ \mathrm{vol})$ and placed on recipient homotypic CMEC cultures initiated on the same day and at the same density as endothelial cells used in coculture with myocytes.

Analysis of preproendothelin and TGF precursor $m R N A$. Total RNA was isolated from cultured cells and rat hearts using guanidinium thiocyanate extraction and cesium chloride sedimentation as previously described $(15,17)$. In some experiments, cocultured CMEC were separated from ARVM by treatment with $0.05 \%$ trypsin for $3 \mathrm{~min}$ at $37^{\circ} \mathrm{C}$, and total RNA was isolated separately from the suspended endothelial cells and myocytes remaining on the tissue culture plates. $15 \mu \mathrm{g}$ of total RNA was size-fractionated by gel electrophoresis, blotted to a nylon membrane, and hybridized for $24 \mathrm{~h}$ with cDNA probes labeled by the random primer method. The membranes were washed with 0.5 SSC (17) with $0.1 \%$ SDS at $52^{\circ} \mathrm{C}$ and exposed to Kodak X-Omat-RR film for 24 (TGF $\beta 1$ ) or $72 \mathrm{~h}$ ( preproendothelin-1). The cDNA used for preproendothelin hybridization was a 1-kb EcoRI fragment containing a conserved portion of the $3^{\prime}$ untranslated region of human preproendothelin-1 transcript (gift of Dr. S. Orkin, Harvard Medical School). The cDNA for TGF $\beta$ was a SacI/PuvII fragment containing a $0.7-\mathrm{kb}$ portion of the coding region of the porcine TGF $\beta 1$ gene.

Identification of rat TGF $\beta 2$ sequence. To determine the identity of the predominant TGF $\beta$ isoform present in ARVM-CMEC coculture, first-strand cDNA was synthesized from $10 \mu \mathrm{g}$ of total RNA isolated from CMEC after separation from coculture with ARVM using Superscript (Bethesda Research Laboratories, Gaithersburg, MD) and random primers (Promega Corp., Madison, WI) in a final reaction volume of $50 \mu \mathrm{l} .10 \mu \mathrm{l}$ of the first-strand synthesis reaction was used as a template for the polymerase chain reaction (PCR) using degenerative forward and reverse oligonucleotides that spanned amino acids 36-111 within the conserved 112-amino acid region of the TGF $\beta$ superfamily. The forward primer contained an EcoRI recognition site at the $5^{\prime}$ end corresponding to $23 \mathrm{bp}$ between 1,340 and 1,362 of the known rat TGF $\beta 1$ sequence. The reverse primer contained a BglII site and corresponded to 25 bp between 1,561 and 1,585 of the rat TGF $\beta 1$ sequence. The PCR reaction (Perkin-Elmer Corp., Norwalk, CT) was carried out at $94^{\circ} \mathrm{C}$ for $1 \mathrm{~min}, 42^{\circ} \mathrm{C}$ for $2 \mathrm{~min}$, and $72^{\circ} \mathrm{C}$ for $2 \mathrm{~min}$ for 30 cycles. The resulting fragments were digested with EcoRI and BglII, gel purified, and ligated into the vector (Bluescript II SK + ; Stratagene, Inc., La Jolla, CA), which had been linearized with BamHI and EcoRI. The recombinant plasmids were amplified using standard techniques, and an initial 10 colonies were grown up for sequence analysis (Sequenase, v 2.0; U. S. Biochemical Corp., Cleveland, $\mathrm{OH}$ ) and compared with known TGF $\beta$ isoform sequences.

Rate of CMEC proliferation in coculture with ARVM. The rate of proliferation of CMEC was assessed by $\left[{ }^{3} \mathrm{H}\right.$ ] thymidine uptake and by direct cell counting. CMEC and ARVM were incubated with $1 \mu \mathrm{Ci} / \mathrm{ml}$ of [ methyl- ${ }^{3} \mathrm{H}$ ] thymidine (New England Nuclear, Boston, MA) at successive time points after initiation of each culture. After a 24-h incubation in labeled thymidine, cells were washed and scraped into ice-cold $10 \%$ TCA, washed and dissolved in $0.12 \mathrm{~N} \mathrm{NaOH}$ with $0.1 \%$ SDS, and radioactivity was determined by scintillation counting. To separate CMEC from ARVM in specified experiments, heterocellular cocultures (and rat CMEC or ARVM controls) were gently trypsinized $(0.05 \%)$ for $3 \mathrm{~min}$ at $37^{\circ} \mathrm{C}$, which resulted in rapid detachment of CMEC under these conditions, leaving most ARVM attached to the laminin-coated dish. Each cell type was then processed as described above. To quantitate changes in cell number, CMEC from homotypic and heterotypic primary cultures were counted directly using a hemacytometer.

For experiments examining the effect of TGF $\beta$-specific antibodies, either CMEC monocultures or CMEC-ARVM cocultures were spiked with $\left[{ }^{3} \mathrm{H}\right]$ thymidine at day 5 . In treated groups, monocultures of CMEC were treated with exogenous TGF $\beta 2(500 \mathrm{pg} / \mathrm{ml})$ at day 5 of culture, with or without additional anti-TGF $\beta$ antibody $(10 \mu \mathrm{g} / \mathrm{ml})$ whereas cocultures of CMEC and ARVM were treated only with antiTGF $\beta$ antibody $(10 \mu \mathrm{g} / \mathrm{ml}) .24 \mathrm{~h}$ after addition of $\left[{ }^{3} \mathrm{H}\right]$ thymidine, cells were harvested and $\left[{ }^{3} \mathrm{H}\right]$ thymidine incorporation was measured as described above.

\section{Results}

Abundance of preproendothelin $\mathrm{MRNA}$ in ARVM-CMEC coculture. Preproendothelin mRNA was not detected in confluent primary cultures of CMEC maintained in medium containing $20 \%$ FCS, although constitutively high levels of endothelin precursor mRNA were easily detected in confluent bovine aortic endothelial cells (BAECs) (Fig. $1 A$ ). Ventricular myocytes maintained in serum-containing medium at $14 \mathrm{~d}$ did not have detectable levels of endothelin precursor transcripts. However, when CMEC were added to established 1-wk ARVM cultures, detectable levels of preproendothelin mRNA became apparent by day 7 of coculture. In a separate experiment, dissociation of CMEC from myocytes in coculture before isolation of total RNA from both cell types indicated that all the preproendothelin hybridization signal was present in RNA derived from endothelial cells (data not shown).

These data suggested that a signal for the induction of endothelin transcription was being received by microvascular endothelial cells in coculture. To determine whether CMEC would respond to several known endothelin secretagogues in large vessel endothelial cells, thrombin, angiotensin II, and TGF $\beta$-1 (14), the effects of these agents as well as conditioned medium from established ARVM monocultures and ARVMCMEC cocultures were examined on preproendothelin mRNA abundance in homotypic CMEC cultures. CMEC were exposed to these reagents at day 5 for $48 \mathrm{~h}$. As shown in Fig. $1 B$, preproendothelin mRNA was below the level of detection in control CMEC monocultures, but transcripts were readily detected in RNA isolated from microvascular endothelial cells exposed to secretagogues. Importantly, addition of 50\% ( $\mathrm{vol} /$ vol) medium conditioned by heterotypic cultures of ARVM and CMEC, harvested on days 5 and 6 of coculture, also induced endothelin transcription [CM $(C M E C / A R V M)$ in Fig. $1 B]$. Exposure of CMEC monocultures to medium condi- 

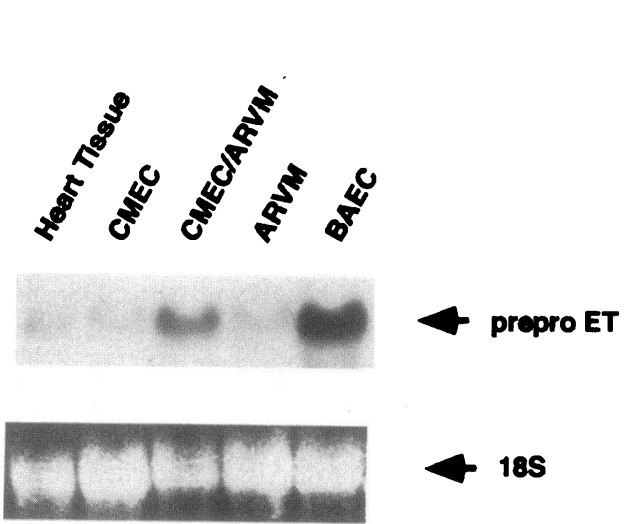

B

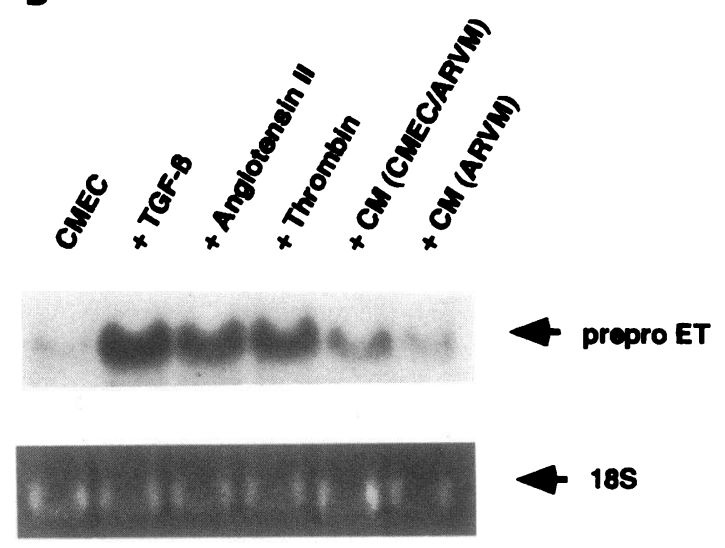

Figure 1. Increase in preproendothelin mRNA in cardiac microvascular endothelial cells by heterotypic coculture with ARVM. ( $A$ ) A representative Northern analysis of preproendothelin mRNA abundance in total RNA from adult rat heart (ventricular) tissue, homotypic confluent cultures of cardiac microvascular endothelial cells $(C M E C)$, adult rat ventricular myocytes $(A R V M)$, bovine aortic

endothelial cells ( $B A E C s)$, or heterotypic primary cultures of microvascular endothelial cells and ventricular myocytes $(A R V M)$. Four additional experiments yielded similar results. $(B)$ Northern analysis of total RNA probed for preproendothelin transcripts in confluent monocultures of CMEC. Known endothelin secretagogues were added to CMEC for $48 \mathrm{~h}$ from days 5 to 7 after initiation of homotypic primary culture (i.e., 100 $\mu \mathrm{M}$ angiotensin $\mathrm{II}, 1 \mathrm{ng} / \mathrm{ml}$ TGF $\beta 1$, or $10 \mathrm{IU} / \mathrm{ml}$ thrombin), as was medium conditioned by prior exposure to heterotypic ARVM-CMEC cocultures ( $50 \%$, vol/vol; lane 5 ) and medium conditioned by homotypic primary cultures of ARVM ( $50 \%$ vol/vol; lane 6$)$. Ethidium bromide fluorescence of $18 \mathrm{~S}$ ribosomal subunit mRNA is shown in the lower panels of both figures.

tioned by adult myocytes alone after $14 \mathrm{~d}$ in monoculture had no effect on endothelin transcription [ $C M(A R V M)$ Fig. $1 B]$.

Role of $T G F \beta$ in regulation of preproendothelin $M R N A$ abundance in $C M E C$. Although only a modest increase in endothelin precursor transcription was apparent at a relatively high concentration of angiotensin II, TGF $\beta 1$ markedly enhanced preproendothelin mRNA levels in CMEC. The TGF $\beta 1$ concentration-effect relation shown in Fig. 2 indicated that the response of monocultured CMEC to this cytokine was bimodal, with peak levels of preproendothelin mRNA at $\sim 500$ $\mathrm{pg} / \mathrm{ml}$ after a 48-h incubation. To evaluate further the role of TGF $\beta$ in the expression of preproendothelin in ARVMCMEC cocultures, the abundance of TGF $\beta$ transcripts was examined. As shown in Fig. 3, low levels of TGF $\beta$ transcription could be identified in both cardiac microvascular endothelial and adult ventricular myocyte homotypic primary cultures under the conditions employed here. Levels of TGF $\beta$ precursor transcripts were enhanced 2.4-fold after $7 \mathrm{~d}$ of coculture compared with parallel homotypic CMEC cultures.

As microvascular endothelial cells could be removed from established ARVM-CMEC cocultures relatively efficiently using low concentrations of trypsin, total RNA was analyzed from the myocyte and endothelial cell fractions from heterotypic ARVM-CMEC primary cultures following trypsinization. As shown in Fig. 3, the hybridization signal for TGF $\beta$ was

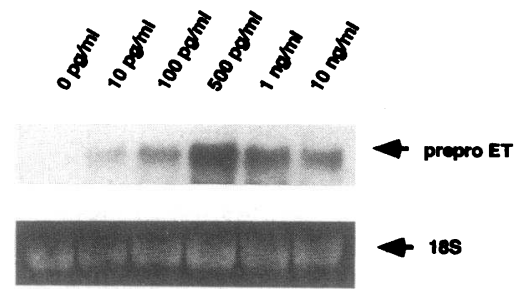

Figure 2. Bimodal action of increasing concentrations of TGF $\beta$ on abundance of preproendothelin mRNA. Total RNA from CMEC monocultures was probed for evidence of endothelin precursor

transcripts $48 \mathrm{~h}$ after addition of increasing concentrations of exogenous TGF $\beta 1$ on day 7 after initiation of primary culture. Similar data were obtained in two separate experiments. increased 2.9-fold in total RNA isolated from trypsinized suspensions of CMEC [Fig. 3, CMEC (tryp)] when compared with CMEC in monoculture whereas a lower hybridization signal was detected in the cells remaining on culture plates after trypsinization, most of which were ventricular myocytes [Fig. 3, $\operatorname{ARVM}($ tryp $)$ ].

These data indicated that TGF $\beta$ was being induced in ARVM-CMEC cocultures and that most if not all of the increase in TGF $\beta$ mRNA abundance was occurring in the microvascular endothelial cells, although a small increase in TGF $\beta$ expression in cocultured myocytes could not be excluded. To determine the time course of appearance of TGF $\beta$ precursor transcripts in relation to endothelin precursor mRNA in CMEC in coculture, total RNA was isolated from parallel heterotypic cultures at 24-h intervals. As shown in Fig. 4, preproendothelin mRNA was not detectable and TGF $\beta$ precursor mRNA remained at low, but detectable levels on days 1-3 of coculture. After $3 \mathrm{~d}$ of coculture, TGF $\beta$ mRNA had begun to increase and, by day 4 , endothelin precursor transcripts were detectable by Northern analysis, with increasing levels of both
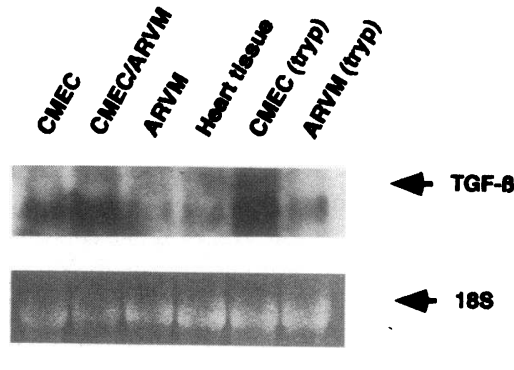

Figure 3. Coculture of CMEC with ARVM increases TGF $\beta$ mRNA levels in endothelial cells. Representative Northern analysis of total RNA revealed low, but detectable levels of TGF $\beta$ gene transcription in homotypic primary cultures of both

CMEC and ARVM. However, TGF $\beta$ transcript levels were increased 2.4-fold by $7 \mathrm{~d}$ of coculture (lane 2, CMEC/ARVM) $(n=5)$. After cell separation by brief exposure to trypsin, the majority of the TGF $\beta$ mRNA hybridization signal was contributed by microvascular endothelial cells [CMEC (tryp)] and not by adult rat ventricular myocytes $[\operatorname{ARVM}(\operatorname{tryp})]$. Similar data were obtained in two additional experiments. 


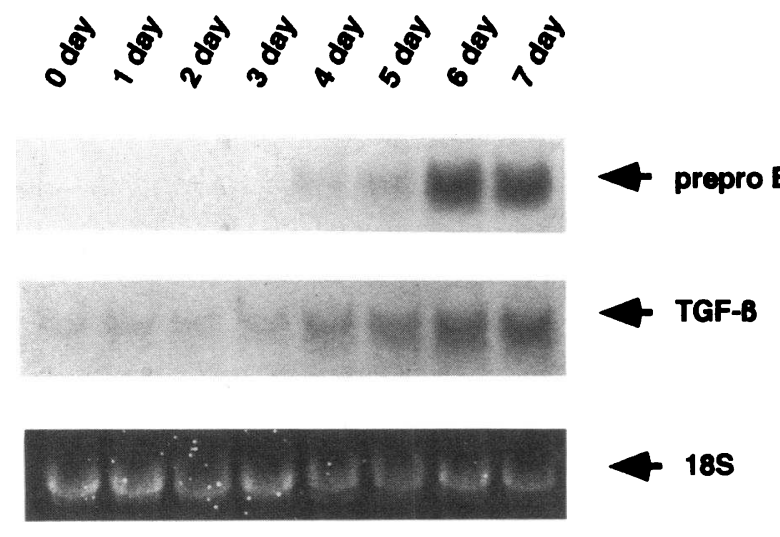

Figure 4. Time course of appearance of TGF $\beta$ and endothelin precursor transcripts in CMEC/ARVM coculture. Representative Northern analysis of TGF $\beta$ and endothelin precursor mRNA at successive time points after initiation of heterotypic coculture $(n=2)$.

transcripts present on subsequent days. These data implied that if TGF $\beta$ were an intermediate in increasing levels of endothelin precursor mRNA, it was acting in an autocrine fashion, with its own transcription and synthesis and subsequent activation induced by yet another signal(s) received from myocytes in coculture.

Identification of TGF $\beta$ isoform( $s$ ) present in coculture. To determine which TGF $\beta$ isoforms were present, PCR amplification was performed on total RNA isolated from cocultured CMEC. Forward and reverse degenerative oligonucleotides primed and equally amplified a PCR assay using porcine TGF $\beta 1$, murine TGF $\beta 2$, and murine TGF $\beta 3$ as templates. Se-

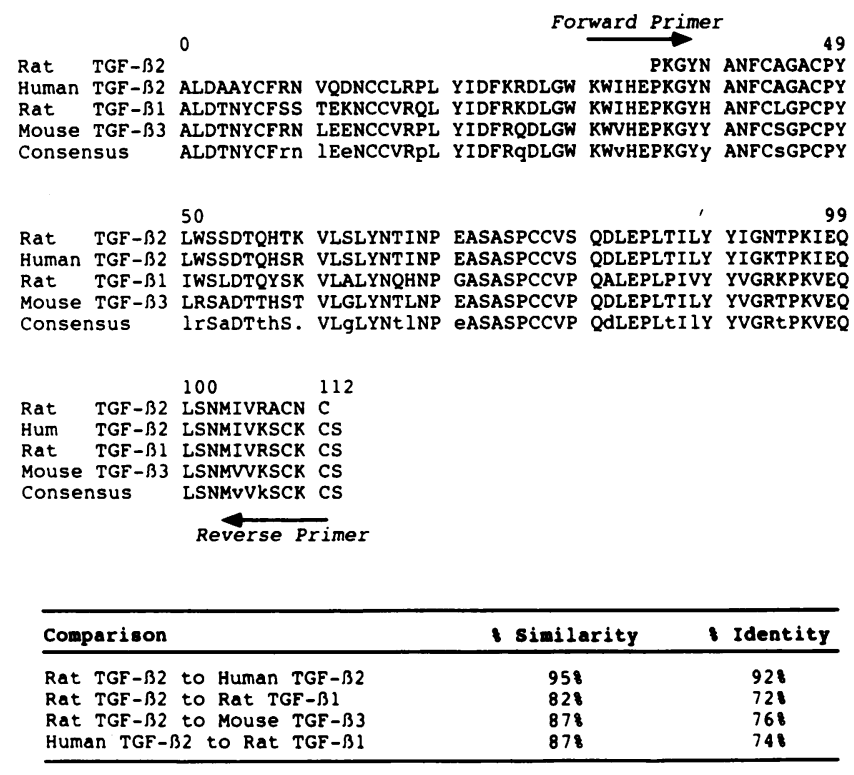

Figure 5. Determination of TGF $\beta 2$ as the predominant TGF $\beta$ isoform mRNA present in heterotypic cocultures of CMEC and ARVM. The deduced amino acid sequences are shown for the PCR product generated from total RNA for ARVM-CMEC cocultures using degenerative oligonucleotide primers within a conserved region of the TGF $\beta$ superfamily (see Methods). The positions of the two primers are indicated by the arrows. Approximately $80 \%$ of PCR-amplified, TGF $\beta$-positive clones exhibited a HindIII restriction enzyme site unique to the deduced rat TGF $\beta 2$ sequence shown here. quence analysis was performed on 10 clones found to be positive for conserved sequences among the TGF $\beta$ isoforms. As shown in Fig. 5, the clones sequenced revealed a deduced amino acid sequence that was $>92 \%$ identical to human TGF $\beta 2$ but only $72 \%$ identical to the rat TGF $\beta 1$ sequence and $76 \%$ identical to the mouse TGF $\beta 3$ sequence. This high degree of sequence conservation for TGF $\beta 2$, as well as for each of the other isoforms across species, is consistent with other reports in the literature, as is the $60-80 \%$ degree of identity for the mature, processed sequences among the five known isoforms of the TGF $\beta$ family $(18,19)$. As a HindIII restriction site unique to the rat TGF $\beta 2$ sequence was identified, restriction site analysis was performed on an additional 20 clones. Of 16 clones successfully analyzed, 13 had the HindIII site present in the rat TGF $\beta 2$ sequence.

$T G F \beta$ antibodies prevent increases in preproendothelin $m R N A$ in coculture. Although the data presented above strongly implicated TGF $\beta$ in the regulation of preproendothelin transcript levels by ARVM in coculture with microvascular endothelial cells, direct evidence for the presence of active TGF $\beta$ was elicited using anti-TGF $\beta$ antibodies. Two antibodies were used: $A b 1$ is nonselective for the mammalian TGF $\beta$ isoforms whereas $\mathrm{Ab} 3$ is an antibody selective for epitopes on TGF $\beta 2$ and TGF $\beta 3$ (20). As shown in Fig. 6, neither antibody, as expected, had any effect on the low constitutive levels of endothelin precursor mRNA in CMEC monocultures. Ab1 $(10 \mu \mathrm{g} / \mathrm{ml})$ almost completely abrogated the expected increase of preproendothelin mRNA by TGF $\beta 1(500 \mathrm{pg} / \mathrm{ml})$ whereas Ab3 had little effect (Fig. 6, lanes 4-6). When added to established ARVM-CMEC cocultures, both antibodies were effective in reducing levels of preproendothelin transcripts (Fig. 6, lanes 7-9). This evidence, coupled with the high prevalence of TGF $\beta 2$-specific clones revealed by PCR analysis, suggests a

Mono-culture Co-culture

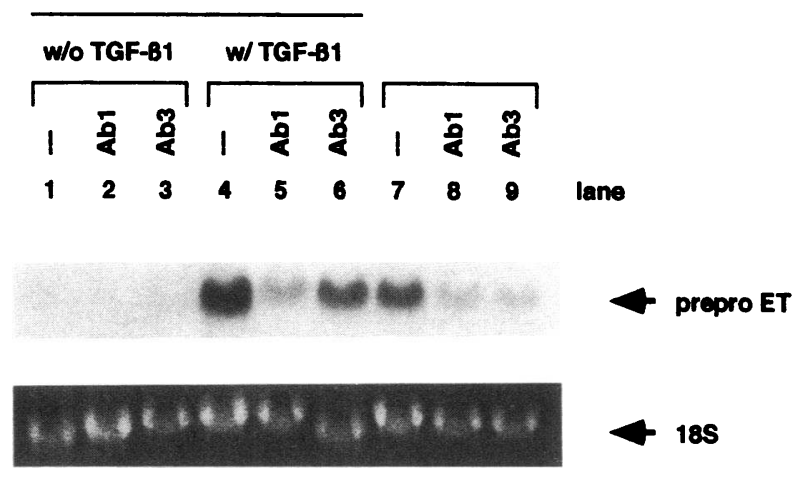

Figure 6. Antibodies to TGF $\beta$ prevent appearance of preproendothelin transcripts in heterotypic CMEC/ARVM primary cultures. Antibody $1(A b 1)$ was nonselective for TGF $\beta$ isoforms whereas antibody $3(A b 3)$ was selective for TGF $\beta 2$ and TGF $\beta 3$; neither antibody alone affected endothelin precursor mRNA abundance (lanes 1-3). An excess of $\mathrm{Abl}(10 \mu \mathrm{g} / \mathrm{ml})$ prevented the expected increase in endothelin precursor transcript levels with exogenous TGF $\beta 1(500 \mathrm{ng} / \mathrm{ml}$, lanes 4 and 5) whereas $\mathrm{Ab3}$ had little effect (lane 6). However, an excess (i.e., $10 \mu \mathrm{g} / \mathrm{ml}$ ) of either $\mathrm{Ab} 1$ or $\mathrm{Ab} 3$, both of which have overlapping specificities for TGF $\beta 2$ and TGF $\beta 3$, reduced preproendothelin mRNA when added to heterotypic ARVM-CMEC cultures (lanes 8 and 9). 


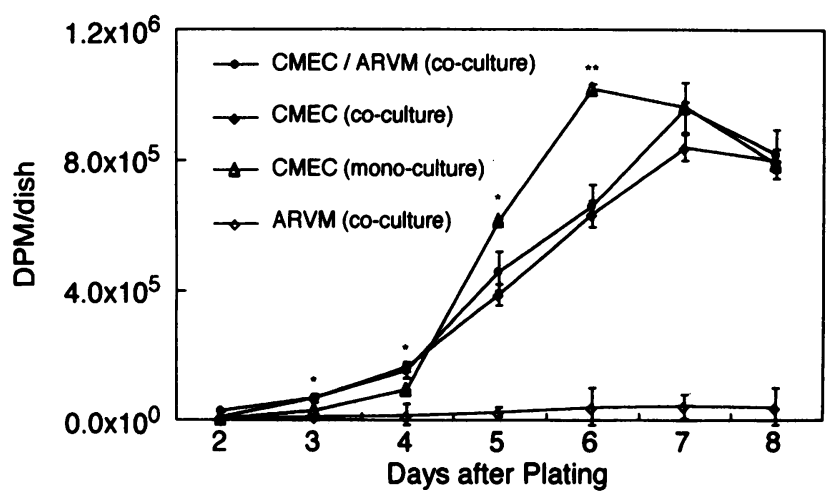

B

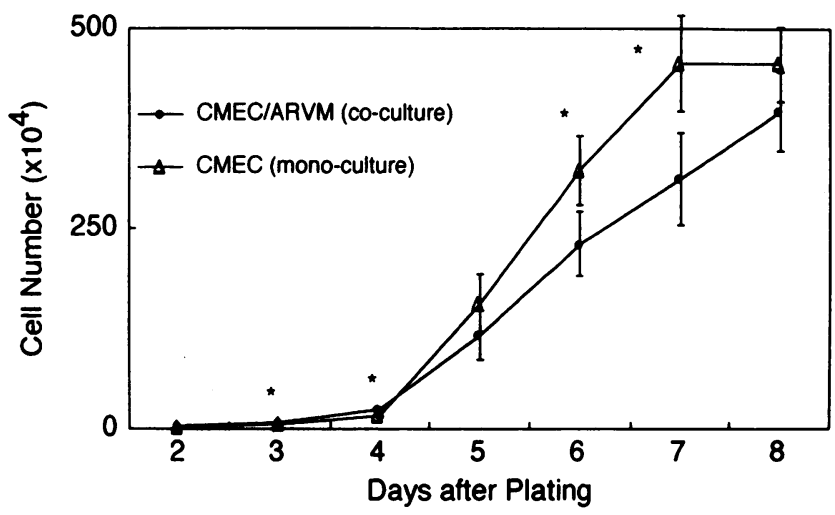

c

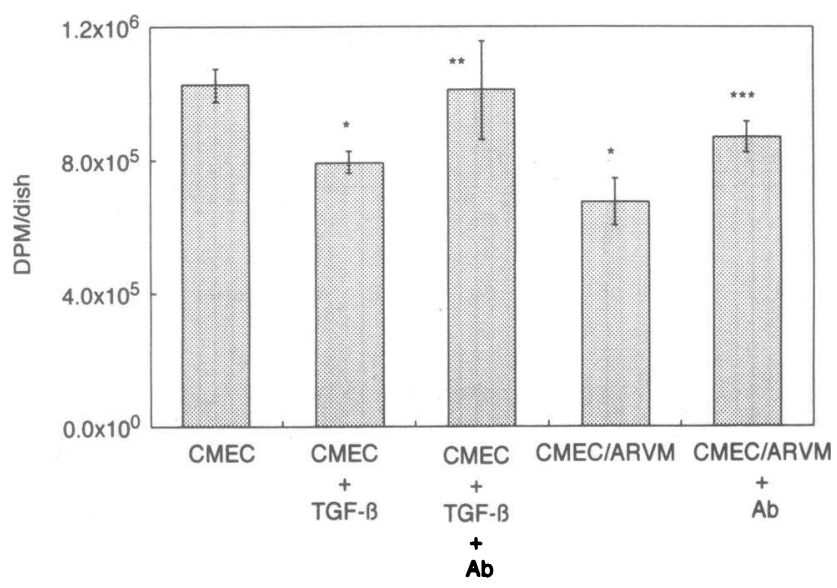

Figure 7. Inhibition of microvascular endothelial cell proliferation by endogenous TGF $\beta$ in heterotypic CMEC/ARVM cultures. ( $A$ ) CMEC in monoculture [CMEC (mono-culture)] and coculture with ARVM [CMEC/ARVM (coculture)] were spiked with $1 \mu \mathrm{Ci} / \mathrm{ml}$ of $\left[{ }^{3} \mathrm{H}\right]-$ thymidine for $24 \mathrm{~h}$ at successive time points from day 1 to day 7 and the amount of $\left[{ }^{3} \mathrm{H}\right]$ thymidine incorporation into CMEC was determined. Note that the anti-proliferative agent cytosine arabinoside used in the isolation and initiation of ARVM primary cultures was removed at initiation of CMEC/ARVM coculture on day 0 . In some experiments, cocultured CMEC were separated from ARVM using $0.05 \%$ trypsin and the $\left[{ }^{3} \mathrm{H}\right]$ thymidine incorporation into the endothelial cell fraction [i.e., CMEC (coculture); solid diamonds] and role for this $\mathrm{TGF} \beta$ isoform in the regulation of endothelin precursor transcripts in cardiac microvascular endothelium, although the data do not exclude the possibility that TGF $\beta 3$ is also involved.

Decreased rate of proliferation of $C M E C$ in coculture: role of $T G F \beta$. When endothelial cells were plated in coculture with ARVM at a relatively low density (2.5 compared with 8.5 $\times 10^{3}$ cells $/ \mathrm{cm}^{2}$ for ARVM), approximately a ratio of $1: 3$, endothelial cell proliferation was increased within the first 3-4 d after initiation of ARVM-CMEC cocultures when contrasted to CMEC in monoculture plated at the same density, as previously shown (16). However, coincident with the increased expression of TGF $\beta$ in heterotypic ARVM-CMEC cultures, both $\left[{ }^{3} \mathrm{H}\right]$ thymidine uptake into CMEC and endothelial cell number declined in coculture after day 5 when compared with parallel homotypic cultures of CMEC (Figs. 7, $A$ and $B)$. This temporal correlation implied a direct role for endogenous TGF $\beta$ in the regulation of endothelial cell growth in vitro. To explore this possibility, the effects of TGF $\beta$-specific antibodies on CMEC proliferation were examined in monoculture and in ARVM-CMEC coculture, respectively. Exogenous TGF $\beta$ added to CMEC $5 \mathrm{~d}$ after initiation of homotypic primary culture significantly decreased the rate of $\left[{ }^{3} \mathrm{H}\right]$ thymidine uptake into microvascular endothelial cells, a decline that could be prevented by addition of TGF $\beta$-specific antibodies (Fig. $7 C$ ). Importantly, an antibody selective for TGF $\beta 2$ and TGF $\beta 3$ when added to heterotypic ARVM-CMEC cultures prevented the expected decrease in the rate of $\left[{ }^{3} \mathrm{H}\right]$ thymidine incorporation associated with coculture (Fig. $7 C$ ). Addition of TGF $\beta$-specific antibodies to parallel homotypic CMEC cultures had no effect on $\left[{ }^{3} \mathrm{H}\right]$ thymidine incorporation rates (data not shown ). It was also possible that endothelins, the transcription of which increases after day 4 of coculture, could have contributed to the decline in CMEC proliferation in coculture. However, $\left[{ }^{3} \mathrm{H}\right]$ thymidine uptake was found to increase in primary culture of homotypic CMEC after addition of exogenous endothelins, but only at relatively high concentrations $\left(\mathrm{EC}_{50}\right.$ $=150 \mathrm{nM})($ data not shown $)$.

remaining ARVM fraction [ $A R V M$ (coculture); open diamonds] was determined separately. $(B)$ CMEC number was determined by direct cell counting from day 2 to day 8 of culture. CMEC were isolated from heterotypic coculture [CMEC/ARVM (coculture); closed circles] and parallel monocultures [CMEC (monoculture); open diamonds) using trypsin. [mean $\pm \mathrm{SD} ;{ }^{*} P<0.05$ and ${ }^{* *} P<0.005$ between cocultured CMEC and monocultured CMEC using Scheffe's test after analysis of variance.] $(C)$ The effect of TGF $\beta$ antibodies on $\left[{ }^{3} \mathrm{H}\right.$ ] thymidine incorporation into CMEC over $24 \mathrm{~h}$ was examined. CMEC in monoculture (CMEC) and coculture (CMEC/ARVM) were incubated with $1 \mu \mathrm{Ci} / \mathrm{ml}$ of $\left[{ }^{3} \mathrm{H}\right]$ thymidine at day 5 . In parallel cultures, monocultured CMEC were treated with either TGF $\beta 2$ ( 500 $\mathrm{pg} / \mathrm{ml})$ alone $(C M E C+T G F \beta)$ or a combination of TGF $\beta 2(500$ $\mathrm{pg} / \mathrm{ml})$ with a TGF $\beta$ antibody $(10 \mu \mathrm{g} / \mathrm{ml})(C M E C+T G F \beta+A b)$ and cocultured CMEC were treated with a TGF $\beta$ antibody $(10 \mu \mathrm{g} /$ $\mathrm{ml})(C M E C / A R V M+A b)$ at day 5 . [mean $\pm \mathrm{SD} ;{ }^{*} P<0.05 \mathrm{com}$ pared with CMEC monoculture $(C M E C) ;{ }^{* *} P<0.05$ compared with CMEC monoculture treated with exogenous TGF $\beta 2$ (CMEC $+T G F \beta) ;{ }^{* * *} P<0.05$ compared with CMEC cocultured with AR.VM $(C M E C-A R V M)$. Each statistic was derived using Scheffe's test after analysis of variance.] 


\section{Discussion}

Recently, Nathan and Sporn (21) suggested that soluble (glyco)peptide signaling factors that are produced locally within a tissue and act in a paracrine and / or autocrine manner collectively be termed "cytokines", a classification that we have extended to the endothelin isoforms (4). They indicated also that the activity of cytokines should be considered in their biological context within a tissue, including the composition of the extracellular matrix, and the mix of other peptide regulatory factors, neurohumoral factors, and autacoids, several of which may have redundant activities (21).

An additional variable in defining the activity of intercellular signaling factors is the phenotype of the cell type(s) being examined. We have used an established model of ventricular myocytes $(15,17,22-25)$ in which a number of well-documented phenotypic changes occur during adaptation to primary culture. Importantly, by $7-10 \mathrm{~d}$, the point at which we initiated coculture, these cells have achieved a stable, homogeneous, and reproducible phenotype. The isolation of endothelial cells from rat hearts and their extensive characterization as being of microvascular origin has been established by a number of criteria (16). As demonstrated in this report, these cells also differ from large vessel endothelium cultured under identical conditions, by exhibiting undetectable levels of preproendothelin transcripts. Phenotypic distinctions also exist among microvascular endothelial cells isolated from different vascular beds $(26,27)$, emphasizing the importance of using tissue-specific endothelium for in vitro models where appropriate.

The increased expression of endothelin mRNA in CMEC monocultures by exogenous TGF $\beta$ and angiotensin II (Fig. 1 $B$ ) suggested a complex and redundant or possibly additive mechanism for inducing endothelin release by microvascular endothelium (14). Endothelin production is predominantly regulated at the level of transcription, since the precursor peptide is not stored, at least in aortic endothelial cells (14). Additional regulation may occur at the level of degradation of preproendothelin transcripts. Like many cytokines and protooncogene products, endothelin precursor mRNA contains AUUU motifs in the $3^{\prime}$ untranslated region, a sequence that is believed to target mRNA for rapid degradation $(28,29)$. The bimodal effect of TGF $\beta$ on preproendothelin transcription documented in Fig. 2 has been shown for several other actions of this cytokine, including "indirect" mitogenesis of aortic smooth muscle cells (30). However, we cannot exclude the possibility that a portion of the observed decreased preproendothelin mRNA abundance, as a ratio of total RNA, was due to a decline in cell number at the 1 and $10 \mathrm{ng} / \mathrm{ml}$ concentrations of TGF $\beta$.

Both TGF $\beta 1$ and TGF $\beta 2$ have been documented to inhibit endothelial cell proliferation, although the relative sensitivity of large vessel and microvessel endothelium to each isoform appears to differ. Capillary endothelial cells in particular appear to be sensitive to the growth inhibitory effects of TGF $\beta 2$ whereas aortic endothelial cells have been reported to be less responsive $(31,32)$. The means by which TGF $\beta$ inhibits endothelial cell proliferation are unclear, although several mechanisms have been suggested, including modification of the extracellular matrix (33-35) and differential regulation of the protooncogene $c-m y c(36,37)$.

The activation of latent TGF $\beta$ in coculture, in which the active $25-\mathrm{kD}$ homodimer is dissociated from the amino-terminal region of the TGF $\beta$ precursor molecule, has also been demonstrated in serum-containing heterotypic cocultures of pericytes or smooth muscle cells with large vessel endothelial cells $(38,39)$. In this report, only medium conditioned by incubation in ARVM-CMEC cocultures, but not medium conditioned by monocultures of ARVM, could regulate preproendothelin transcript levels in cardiac microvascular endothelial cells (Fig. $1 B$ ). These data imply that contact between ARVM and CMEC in coculture, or close apposition, is necessary for the activation of latent TGF $\beta$. This finding is consistent with previous reports in which neither medium conditioned by monocultured cells nor cocultures of endothelial cells and pericytes in which the two cell types are separated, thus preventing cell-cell contact, resulted in activation of $\operatorname{TGF} \beta(38,39)$.

The mechanism of activation of TGF $\beta$ in coculture is as yet unclear. It is likely that activation of plasminogen and the latent TGF $\beta$-binding protein, which are present in these serumcontaining cultures, play a role. Ventricular myocytes in vivo and in vitro have been shown to contain acidic and basic fibroblast growth factor (40-43), cytokines known to induce release of urokinase-type plasminogen activator in capillary endothelial cells (44). In contrast, TGF $\beta$ has been shown to decrease plasminogen activator activity in large vessel endothelial cells, probably by increasing the rate of transcription of plasminogen activator inhibitor-1 (44).

It has been proposed that $\mathrm{TGF} \beta$ may thereby regulate its own rate of activation $(44,45)$. Thus, if activation of plasmin in serum is responsible for the cleavage of the amino-terminal portion of latent TGF $\beta$, this may reflect a balance between the release of urokinase-type plasminogen activator and plasminogen activator inhibitor-1 at different stages of coculture (46). This still does not explain the apparent necessity for heterotypic cell-cell contact for activation of latent TGF $\beta$. One hypothesis, suggested by Dennis and Rifkin (45), is that latent TGF $\beta$, which may be present in the extracellular matrix and culture medium in vitro, occurs by a process of cell-surface assembly involving one or more cell types, thus providing a means for localizing physiologically relevant concentrations of the active peptide.

The data presented here indicate that endothelial cells, not myocytes, are the source of a TGF $\beta$ isoform, possibly TGF $\beta 2$. The high prevalence of TGF $\beta 2$ transcripts after PCR amplification of total mRNA from ARVM-CMEC cocultures was unexpected given recent reports that TGF $\beta 3$ is the predominant isoform present in the developing heart, at least in the mouse (47), whereas TGF $\beta 2$ expression appears to be transient in both the mouse and chick $(47,48)$. Although immunohistochemical analysis of the normal adult rat ventricle has revealed positive staining for TGF $\beta 1$ within ventricular myocytes and in capillary endothelial cells (49), the relative levels of expression of TGF $\beta$ isoforms in the postnatal mammalian heart have not been extensively characterized.

In summary, intercellular signaling between ventricular myocytes and cardiac microvascular endothelial cells regulates the abundance of precursor transcripts for endothelin, a cytokine that is present in the adult myocardium and that has welldescribed effects on myocyte function and gene expression. Levels of endothelin precursor mRNA in cardiac microvascular endothelial cells are increased by TGF $\beta$, acting as an intermediate autocrine cytokine generated by endothelial cells and 
activated in coculture. TGF $\beta$ synthesis and activation in coculture also diminished the rate of endothelial cell proliferation. These data support the concept that reciprocal intercellular signaling may exist between microvascular endothelium and ventricular muscle cells in the adult myocardium.

\section{Acknowledgments}

We thank Drs. Patricia D'Amore, William Carley, and Mary Gerritsen for advice and assistance, and Dr. D'Amore for reviewing the manuscript. We also thank Drs. James R. Dasch and Larry R. Ellingsworth of Celtrix Laboratories (Palo Alto, CA) for generously supplying recombinant TGF $\beta 1$ and TGF $\beta 2$ peptide and the anti-TGF $\beta$ antibodies used in this study. We also thank Ms. Chandana Saha for superb technical assistance.

This work was supported in part by a postdoctoral fellowship award from the American Heart Association (J. P. Springhorn), a Faculty Development Award from the Pharmaceutical Manufacturers Association (R. A. Kelly), and grant HL36141 from the National Heart, Lung, and Blood Institute, National Institutes of Health (T. W. Smith).

\section{Fieferences}

1. Runyan, R. B., J. D. Potts, and D. L. Weeks. 1992. TGF- $\beta 3$-mediated tissue interaction during embryonic heart development. Mol. Reprod. Dev. 32:152159.

2. Millan, F., F. Denhez, P. Kondaiah, and R. Akhurst. 1991. Embryonic gene expression patterns of TGF- $\beta 1, \beta 2$ and $\beta 3$ suggest different developmental functions in vivo. Development (Camb.). 1211:131-144.

3. Whitman, M., and D. A. Melton. 1989. Growth factors in early embryogenesis. Annu. Rev. Cell Biol. 5:93-117.

4. Kramer, B. K., M. Nishida, R. A. Kelly, and T. W. Smith. 1992. Endothelins. Myocardial actions of a new class of cytokines. Circulation. 85:350-356.

5. Shubeita, H. E., P. M. McDonough, A. N. Harris, K. U. Knowlton, C. C. Glembotski, J. H. Brown, and K. R. Chien. 1990. Endothelin induction of inositol phospholipid hydrolysis, sarcomere assembly, and cardiac gene expression in ventricular myocytes. A paracrine mechanism for myocardial cell hypertrophy. J. Biol. Chem. 265:20555-20562.

6. Brutsaert, D. L., and L. J. Andries. 1992. The endocardial endothelium. Am. J. Physiol. 263:H985-H1002.

7. Meulemans, A. L., and D. L. Brutsaert. 1991. Endocardial endothelium modulates inotropic responses of subjacent myocardium. J. Cardiovasc. Pharmacol. 17:S247-S250.

8. Smith, J. A., A. M. Shah, and M. J. Lewis. 1991. Factors released from endocardium of the ferret and pig modulate myocardial contraction. J. Physiol. 439:1-14.

9. Li, K., D. J. Stewart, and J.-L. Rouleau. 1991. Myocardial contractile actions of endothelin-1 in rat and rabbit papillary muscles. Role of endocardial endothelium. Circ. Res. 69:301-312.

10. Ramaciotti, C., A. Sharkey, G. McClellan, and S. Winegrad. 1992. Endothelial cells regulate cardiac contractility. Proc. Natl. Acad. Sci. USA. 89:40334036.

11. McClellan, G., A. Weisberg, N. S. Kato, C. Ramaciotti, A. Sharkey, and S. Winegrad. 1992. Contractile proteins in myocardial cells are regulated by factor(s) released by blood vessels. Circ. Res. 70:787-803.

12. Kelly, R. A., H. Eid, B. K. Kramer, M. O'Neill, B. T. Liang, M. Reers, and T. W. Smith. 1990. Endothelin enhances the contractile responsiveness of adult rat ventricular myocytes to calcium by a pertussis toxin-sensitive pathway. $J$. Clin. Invest. 86:1164-1171.

13. Kramer, B. K., T. W. Smith, and R. A. Kelly. 1991. Endothelin and increased contractility in adult rat ventricular myocytes. Role of intracellular alkalosis induced by activation of the protein kinase $\mathrm{C}$-dependent $\mathrm{Na}^{+}-\mathrm{H}^{+}$exchanger. Circ. Res. 68:269-279.

14. Masaki, T., S. Kimura, M. Yanagisawa, and K. Goto. 1991. Molecular and cellular mechanism of endothelin regulation. Implications for vascular function. Circulation. 84:1457-1468.

15. Eid, H., D. M. Larson, J. P. Springhorn, M. A. Attawia, R. C. Mayak, T. W. Smith, and R. A. Kelly. 1992. Role of epicardial mesothelial cells in the modification of phenotype and function of adult rat ventricular myocytes in primary coculture. Circ. Res. 71:40-50.

16. Nishida, M., W. W. Carley, M. E. Gerritsen, Ø. Ellingsen, R. A. Kelly, and T. W. Smith. 1993. Isolation and characterization of human and rat cardiac microvascular endothelial cells. Am. J. Physiol. In press.
17. Springhorn, J. P., Ø. Ellingsen, H.-J. Berger, R. A. Kelly, and T. W. Smith. 1992. Transcriptional regulation in cardiac muscle. Coordinate expression of Id with a neonatal phenotype during development and following a hypertrophic stimulus in adult rat ventricular myocytes in vitro. J. Biol. Chem. 267:1436014365.

18. Massague, J. 1990. The transforming growth factor- $\beta$ family. Annu. Rev. Cell Biol. 6:597-641.

19. Roberts, A. B., and M. B. Sporn. 1990. The transforming growth factor- $\beta$ s. In Peptide Growth Factors and Their Receptors I. M. B. Sporn and A. B. Roberts, editors. Springer-Verlag, Berlin. 425-472.

20. Dasch, J. R., D. R. Pace, W. Waegell, D. Inenaga, and L. Ellingsworth. 1989. Monoclonal antibodies recognizing transforming growth factor- $\beta$. Bioactivity neutralization and transforming growth factor $\beta 2$ affinity purification. $\mathrm{J}$. Immunol. 142:1536-1541.

21. Nathan, C., and M. Sporn. 1991. Cytokines in context. J. Cell Biol. 113:981-986.

22. Moses, R. L., and W. C. Claycomb. 1982. Disorganization and reestablishment of cardiac muscle cell ultrastructure in cultured adult rat ventricular muscle cells. J. Ultrastruct. Res. 81:358-374.

23. Bugaisky, L. B., and R. Zak. 1989. Differentiation of adult rat cardiac myocytes in cell culture. Circ. Res. 64:493-500.

24. Jacobson, S. L., and H. M. Piper. 1986. Cell cultures of adult cardiomyocytes as models of the myocardium. J. Mol. Cell. Cardiol. 18:661-678.

25. Claycomb, W. C. 1988. Atrial natriuretic factor mRNA is developmentally regulated in heart ventricles and actively expressed in cultured ventricular cardiac muscle cells of rat and human. Biochem. J. 255:617-620.

26. Kumar, S., D. C. West, and A. Ager. 1987. Heterogeneity in endothelial cells from large vessels and microvessels. Differentiation. 36:57-70.

27. Palade, G. E. 1988. The microvascular endothelium revisited. In Endothelial Cell Biology in Health and Disease. N. Simionescu and M. Simionescu, editors. Plenum Press, New York. 3-22.

28. Bouvet, P., J. Paris, M. Phillipe, and H. B. Osborne. 1991. Degradation of a developmentally regulated mRNA in Xenopus embryos is controlled by the $3^{\prime}$ region and requires the translation of another maternal mRNA. Mol. Cell. Biol. 11:3115-3124.

29. Vakalopoulou, E., J. Schaack, and T. Shenk. 1991. A 32-kilodalton protein binds to AU-rich domains in the 3 ' untranslated regions of rapidly degraded mRNAs. Mol. Cell. Biol. 11:3355-3364.

30. Battegay, E. J., E. W. Raines, R. A. Seifert, D. F. Bowen-Pope, and R. Ross. 1990. TGF- $\beta$ induces bimodal proliferation of connective tissue cells via complex control of an autocrine PDGF loop. Cell. 63:515-524.

31. Merwin, J. R., W. Newman, L. D. Baell, A. Tucker, and J. Madri. 1991. Vascular cells respond differentially to transforming growth factors $\beta 1$ and $\beta 2$ in vitro. Am. J. Pathol. 138:37-51.

32. Jennings, J. C., S. Mohan, T. A. Linkhart, R. Widstrom, and D. J. Baylink. 1988. Comparison of the biological activities of TGF $\beta 1$ and TGF $\beta 2$ differential activity in endothelial cells. J. Cell Physiol. 137:167-172.

33. Mooradian, D. L., and C. A. Diglio. 1990. Effects of epidermal growth factor and transforming growth factor $\beta 1$ on rat heart endothelial cell anchoragedependent and -independent growth. Exp. Cell Res. 186:122-129.

34. Iruela-Arispe, M. L., P. Bornstein, and H. Sage. 1991. Thrombospondin exerts an antiangiogenic effect on cord formation by endothelial cells in vitro Proc. Natl. Acad. Sci. USA. 88:5026-5030.

35. Good, D. J., P. J. Polverini, F. Rastinejad, M. M. Le Beau, R. S. Lemons, W. A. Frazier, and N. P. Bouck. 1990. A tumor suppressor-dependent inhibitor of angiogenesis is immunologically and functionally indistinguishable from a fragment of thrombospondin. Proc. Natl. Acad. Sci. USA. 87:6624-6628.

36. Moses, H. L., E. Y. Yang, and J. A. Pietenpol. 1990. TGF- $\beta$ stimulation and inhibition of cell proliferation: new mechanistic insights. Cell. 63:245-247.

37. Pietenpol, J. A., R. W. Stein, E. Moran, P. Yaciuk, R. Schlegel, R. M. Lyons, M. R. Pittelkow, K. Munger, P. M. Howley, and H. L. Moses. 1990. TGF- $\beta 1$ inhibition of $c-m y c$ transcription and growth in keratinocytes is abrogated by viral transforming proteins with pRB binding domains. Cell. 61:777785 .

38. Antonelli-Orlidge, A., K. B. Saunders, S. R. Smith, and P. A. D'Amore. 1989. An activated form of transforming growth factor $\beta$ is produced by cocultures of endothelial cells and pericytes. Proc. Natl. Acad. Sci. USA. 86:45444548.

39. Sato, Y., R. Tsuboi, R. Lyons, H. Moses, and D. B. Rifkin. 1990. Characterization of the activation of latent TGF- $\beta$ by cocultures of endothelial cells and pericytes or smooth muscle cells: a self-regulating system. J. Cell Biol. 111:757763.

40. Weiner, H. L., and J. L. Swain. 1989. Acidic fibroblast growth factor mRNA is expressed by cardiac myocytes in culture and the protein is localized to the extracellular matrix. Proc. Natl. Acad. Sci. USA. 86:2683-2687.

41. Sasaki, H., H. Hoshi, Y.-M. Hong, T. Suzuki, T. Kato, H. Sasaki, M. Saito, H. Youki, K. Karube, S. Konno, et al. 1989. Purification of acidic fibro- 
blast growth factor from bovine heart and its localization in the cardiac myocytes J. Biol. Chem. 264:17606-17612.

42. Casscells, W. E. Speir, J. Sasse, M. Klagsbrun, P. Allen, M. Lee, B. Calvo, M. Chiba, L. Haggroth, J. Folkman, et al. 1990. Isolation, characterization, and localization of heparin-binding growth factors in the heart. J. Clin. Invest. 85:433-441.

43. Speir, E., V. Tanner, A. M. Gonzalez, J. Farris, A. Baird, and W. Casscells. 1992. Acidic and basic fibroblast growth factors in adult rat heart myocytes. Localization, regulation in culture, and effects on DNA synthesis. Circ. Res. 71:251-259.

44. Mignatti, P. L., R. Mazzieri, and D. B. Rifkin. 1991. Expression of the urokinase receptor in vascular endothelial cells is stimulated by basic fibroblast growth factor. J. Cell Biol. 113:1193-1201.

45. Dennis, P. A., and D. B. Rifkin. 1991. Cellular activation of latent transforming growth factor $\beta$ requires binding to the cation-independent mannose 6-phosphate/insulin-like growth factor type II receptor. Proc. Natl. Acad. Sci. USA. 88:580-584.

46. RayChaudhury, A., and P. A. D'Amore. 1991. Endothelial cell regulation by transforming growth factor-beta. J. Cell. Biochem. 47:224-229.

47. Pelton, R. W., B. Saxena, M. Jones, H. L. Moses, and L. I. Gold. 1991. Immunohistochemical localization of TGF $\beta 1$, TGF $\beta 2$, and TGF $\beta 3$ in the mouse embryo. Expression patterns suggest multiple roles during embryonic development. J. Cell Biol. 115:1091-1105.

48. Potts, J. D., J. M. Dagle, J. A. Walder, D. L. Weeks, and R. B. Runyan. 1991. Epithelial-mesenchymal transformation of embryonic cardiac endothelial cells is inhibited by a modified antisense oligodeoxynucleotide to transforming growth factor $\beta 3$. Proc. Natl. Acad. Sci. USA. 88:1516-1520.

49. Thompson, N. L., F. Bazoberry, E. H. Speir, W. Casscells, V. J. Ferrans, K. C. Flanders, P. Kondaiah, A. G. Geiser, and M. B. Sporn. 1988. Transforming growth factor $\beta-1$ in acute myocardial infarction in rats. Growth Factors. 1:91-99. 